\title{
Increased mitogen-activated protein kinase expression and activity in white adipose tissue of ventromedial hypothalamus-lesioned rats
}

\author{
M. C ombettes-Souverain ${ }^{1}$, L . Pénicaud ${ }^{2}$, P. Ferré ${ }^{1}$, T. I ssad ${ }^{3}$ \\ ${ }^{1}$ Institut National de la Santé et de la Recherche Médicale U-342 Hôpital Saint-Vincent-de-Paul, Paris, France \\ ${ }^{2}$ UPRESA 5018 CNRS, Université Paul Sabatier, Toulouse, France \\ ${ }^{3}$ ICGM, CNRS, UPR 415, Paris, France
}

Summary Ventromedial hypothalamus lesions in rats induce hyperphagia and hyperinsulinaemia associated with a rapid growth of white adipose tissue resulting in massive obesity. It has been shown previously that at an early stage after the lesion, during the dynamic phase of obesity, the white adipose tissue is hyper-responsive to insulin. In the present work, we show that the effects of insulin on the autophosphorylation of the insulin receptor and on its tyrosine-kinase activity towards endogenous substrates are similar in intact adipocytes of control and ventromedial hypothalamus lesioned rats. One week after the lesion, the expression of phosphatidylinisitol 3-kinase and RAF-1 kinase, evaluated by Western-blotting, was similar in control and ventromedial hypothalamus lesioned rats. In contrast, an important increase in the expression of extracellular signal regulated kinase 1 protein was observed in white adipose tissue of ventromedial hypothalamus lesioned compared to control animals. No difference in the expression of extracellular signal regulated kinase $1 \mathrm{mRNA}$ was observed in adipose tissue of control and ventromedial hypothalamus lesioned rats, suggesting that a posttranscriptional mechanism is involved in the over-expression of extracellular signal regulated kinase 1. The kinase activity of extracellular signal regulated kinase 1 and 2 is also markedly increased in adipocytes of ventromedial hypothalamus lesioned compared to control rats, both in the basal state and after insulin stimulation. Six weeks after the ventromedial hypothalamus lesion, this increase in mitogen-activated protein kinase expression and activity was still observed in adipocytes of ventromedial hypothalamus lesioned rats. These results suggest that an early and sustained increase in the expression and activity of mitogen-activated protein kinase may participate in the development of white adipose tissue in ventromedial hypothalamus lesioned rats. [Diabetologia (1997) 40: 533-540]

Keywords Insulin signalling, MAP-kinase, insulin receptor, insulin sensitivity, obesity, white adipose tissue.
Received: 16 December 1996

and in revised form: 12 February 1997

Corresponding author: Dr. T. Issad, ICGM, CNRS UPR 415, 22 rue Méchain, F-75014 Paris, France

A bbreviations: VMH, Ventromedian hypothalamus; MAPK, mitogen-activated protein kinase; ERK, extracellular signal regulated kinase; PMSF, phenylmethylsulfonyl fluoride; WAT, white adipose tissue; IR, insulin receptor; PI3K, phosphatidylinisitol 3-kinase; SDS/PAGE, sodium dodecyl sulfate/polyacrylamide gel electrophoresis; IP, immunoprecipitation; FAS, fatty-acid synthase; PEPCK, phosphoenolpyruvate carboxykinase.
In rats made obese by electrolytic lesion of the ventromedial hypothalamus (VMH), the onset of the syndrome is determined by the time of the lesion, allowing a chronological study of the alterations associated with obesity. Lesion of the VMH induces hyperphagia, hyperinsulinaemia and obesity [1], associated with alterations in the cellularity and metabolism of the white adipose tissue (WAT). After the lesion, there is an initial period of rapid weight gain (dynamic phase) followed by a slowing in the rate of weight gain (static phase). During the dynamic phase of the VMH obesity, a state of hyperresponsiveness to insulin is observed in white adipose tissue [2]. This 
hyperresponsiveness to insulin is associated with an increased expression of distal effectors of insulin action such as the insulin-sensitive glucose transporter Glut-4 and lipogenic enzymes (fatty acid synthase and acetyl-CoA carboxylase) [3].

Changes in the expression and/or activity of effectors involved in insulin signal transduction could also play a role in this state of hyper-responsiveness. Binding of insulin to its receptor induces autophosphorylation of the insulin receptor (IR), leading to the subsequent tyrosine phosphorylation of cellular proteins, such as insulin receptor substrate-1 (IRS-1 or pp185), a major target for insulin receptor kinase activity [4]. Upon tyrosine phosphorylation, IRS-1 complexes with the enzyme phophatidylinositol (PI)3-kinase, which could play an essential role in insulin-induced glucose transporter translocation in rat adipocytes [4]. IRS-1 also binds to the Grb2/Sos complex [4], which then activates Ras, a GTP-binding protein. Sequential activation of Ras, Raf and the mitogen-activated-protein kinase kinase by insulin leads to the stimulation of the mitogen-activated protein kinase (MAPK) isoforms pp $44^{\mathrm{MAPK}} / \mathrm{ERK}-1$ and pp $42^{\mathrm{MAPK}} /$ ERK-2. MAPK could play a role in various biological processes such as metabolism, cell growth and proliferation [5].

Alterations in the transmission of insulin signalling are likely to play an important role in the modifications of insulin responsiveness observed in several models of insulin resistance. Studies performed in both streptozotocin-diabetic rats, insulin-resistant old rats and gold-thioglucose obese mice have shown a decreased kinase activity of IR in various tissues, including muscle [6, 7], liver [6] and fat [8]. Moreover, a reduced tyrosine phosphorylation in response to insulin has been described for IRS-1 in liver and muscles of ob/ob mice [9], and for pp60 in adipocytes of goldthioglucose obese mice [8]. In animal models of insulin resistance, alterations of insulin stimulation of PI3K have also been observed in muscle $[6,8,10]$, liver [6] and adipocytes [8]. It has also been shown that the MAPK activation is impaired in skeletal muscle of obese insulin-resistant mice [11].

The aim of the present work was to determine whether the increase in insulin responsiveness observed in WAT of VMH rats is also associated with modification of the expression and/or activity of proteins involved in the insulin signalling pathway.

\section{Materials and methods}

M aterials. Collagenase, protein A-sepharose, $\mathrm{CNBr}$ activated sepharose, Triton X-100, bovine serum albumin, aprotinin, pepstatin, antipain, leupeptin, phenylmethylsulfonyl fluoride (PMSF), sodium orthovanadate, myelin basic protein (MBP), dextran sulfate and agarose were from Sigma (Saint-Quentin Fallavier, France). Reagents and secondary antibodies for enhanced chemoluminescence (ECL kit) were from Amersham
(Les Ulis, France). All reagents for sodium dodecyl sulfate (SDS)-polyacrylamide gel electrophoresis were from BioRad (Ivry-sur-Seine, France). Formamide and formaldehyde were from Prolabo (Paris, France). $\left[\alpha-{ }^{32} \mathrm{P}\right] \mathrm{dCTP}, \gamma\left[{ }^{32} \mathrm{P}\right]-\mathrm{ATP}$ and hyperfilms MP, nylon "Hybond-N" membranes, rediprime labelling system kit were from Amersham.

A nimals. Female Wistar rats (IFA Credo, L'Arbresles, France) weighing 200-220 g were housed in a room with light on from 07.00 to 19.00 hours and had free access to water and laboratory chow.

Rats were anaesthetized intraperitoneally with $95 \mathrm{mg}$ ketamine/kg body weight (Imalgene 500, Bio-Mérieux, France), and $\mathrm{VMH}$ lesions were carried out as described previously [12]. Experiments were performed 1 week after the VMH lesion. In some experiments, VMH rats were also studied 6 weeks after the VMH lesion, during the static phase of obesity. Control and VMH rats were killed by cervical dislocation. Periovarian WAT was rapidly removed, and either used for adipocyte isolation or frozen in liquid nitrogen and stored at $-80^{\circ} \mathrm{C}$ for subsequent analysis.

Fat cell size and D N A content. Diameters of fat cells were measured under a microscope on adipose tissue slices, floating in an iso-osmolar solution. The slices were obtained by freeze cutting after a brief formaldehyde fixation. All cells in a given part of the slice were measured. The calculation of the fat cell size was performed as previously described [13]. DNA content was measured by a spectrofluorometric assay [14].

Cell preparation. White adipocytes from control and VMH rats were isolated as described previously [15]. The periovarian fat pads were removed and washed in Krebs-Ringer-bicarbonate buffer, $\mathrm{pH}$ 7.4, supplemented with $10 \mathrm{mmol} / \mathrm{l}$ HEPES containing $1 \mathrm{mmol} / \mathrm{l} \mathrm{CaCl}_{2}$ (buffer $\mathrm{A}$ ). The tissue was cut into small pieces and digested for $1 \mathrm{~h}$ in the buffer A containing $1 \mathrm{mg} / \mathrm{ml}$ collagenase in a shaking water bath at $37^{\circ} \mathrm{C}$. The digested tissue was then filtered through a $200-\mu \mathrm{m}$ nylon mesh and the isolated cells were washed three times in buffer A devoid of collagenase. Adipocytes from VMH and control rats $\left(6 \times 10^{6}\right.$ cells $)$ were stimulated for $5 \mathrm{~min}$ with insulin $(67 \mathrm{nmol} / \mathrm{l})$ in buffer A supplemented with $1 \mathrm{mmol} / 1 \mathrm{CaCl}_{2}$ and $4 \%(\mathrm{w} / \mathrm{v})$ fatty-acidfree bovine serum albumin. Incubations were stopped as described previously [16] by adding $6 \mathrm{ml}$ of ice-cold extracting buffer (100 mmol/l HEPES, pH 7,6, 2\% Triton X-100, $40 \mathrm{mmol} / 1 \mathrm{EDTA}, 20 \mathrm{mmol} / \mathrm{l} \mathrm{NaF}, 60 \mathrm{mmol} / \mathrm{l}$ sodium pyrophosphate, $4 \mathrm{mmol} / \mathrm{l}$ benzamidine, $2 \mathrm{mmol} / 1 \mathrm{Na}_{3} \mathrm{VO}_{4}, 2 \mathrm{mmol} / \mathrm{l}$ PMSF and $2 \mu \mathrm{g}$ each of aprotinin, pepstatin, antipain and leupeptin) into the incubation buffer. The vials were then immediately frozen in liquid nitrogen. The extracts were allowed to thaw out slowly at $4{ }^{\circ} \mathrm{C}$. After centrifugation of $10000 \mathrm{~g}$ for $10 \mathrm{~min}$, the fat cake and the insoluble material were discarded. The soluble extracts were then collected for subsequent analysis.

A dipose tissue extraction. In some experiments, WAT (400$500 \mathrm{mg}$ ) from control and $\mathrm{VMH}$ rats was directly homogenized with a polytron in $5 \mathrm{ml}$ of extraction buffer $20 \mathrm{mmol} / \mathrm{l} \mathrm{MOPS}$, $\mathrm{pH} 7.4$, and containing $2.5 \mathrm{mmol} / \mathrm{l}$ benzamidine, $1 \mathrm{mmol} / \mathrm{l}$ EDTA, $0.1 \%$ Triton X-100, $1 \mu \mathrm{g} / \mathrm{ml}$ each of leupeptin, antipain, and pepstatin. The homogenate was centrifuged at $10000 \mathrm{~g}$ for $30 \mathrm{~min}$. The supernatants were then collected and used for immunoprecipitation.

Immunoprecipitation. Immunoprecipitation was performed using the following antibodies: CT1 (anti-insulin-receptor antibody kindly provided by Prof. K. Siddle, University of 
Cambridge, UK) [17], anti-ERK1 (K23, Santa Cruz, USA), anti-ERK2 (CI4; Santa Cruz), anti-PI3K (PI3K; Santa Cruz), anti-Raf1-K (C-12sc133; Santa Cruz). Antibodies were absorbed on protein-A sepharose (1.25 mg protein-A sepharose/ $\mu l$ antiserum) except for CT1 antibody which was covalently linked to $\mathrm{CNBr}$-activated sepharose as described previously [18]. Immunoprecipitations were carried out for $2 \mathrm{~h}$ at $4^{\circ} \mathrm{C}$. After centrifugation ( $2 \mathrm{~min}, 10000 \mathrm{~g}$ ) the sepharose pellet was washed three times with $4 \mathrm{ml}$ of washing buffer $(50 \mathrm{mmol} / \mathrm{l} \mathrm{He}$ pes, $\mathrm{pH}$ 7.6, 0.1\% Triton X-100, $20 \mathrm{mmol} / 1$ EDTA, $30 \mathrm{mmol} / \mathrm{l}$ $\mathrm{NaF}, 30 \mathrm{mmol} / \mathrm{l}$ sodium pyrophosphate, $2 \mathrm{mmol} / \mathrm{l}$ benzamidine, $1 \mathrm{mmol} / 1 \mathrm{Na}_{3} \mathrm{VO}_{4}, 1 \mathrm{mmol} / \mathrm{l} \mathrm{PMSF}$ and $1 \mu \mathrm{g} / \mathrm{ml}$ each of aprotinin, pepstatin, antipain and leupeptin) and then with $1 \mathrm{ml}$ of this buffer diluted 10-fold in distilled water. The proteins that bound to the sepharose pellet were then eluted by boiling in SDS/PAGE sample buffer containing $2.5 \%$ SDS and $200 \mathrm{mmol} / \mathrm{l}$ dithiothreitol.

In some experiments, after immunoprecipitation with antiinsulin receptor antibody, the cell extracts were incubated with $0.75 \mathrm{ml}$ hydroxyapatite for $2 \mathrm{~h}$ at $4{ }^{\circ} \mathrm{C}$ as previously described [16]. After centrifugation, the proteins absorbed on hydroxyapatite were eluted by boiling in a SDS/PAGE sample buffer containing $2.5 \% \mathrm{SDS}$ and $200 \mathrm{mmol} / \mathrm{l}$ dithiothreitol.

I mmunoblotting. For immunoblotting experiments, proteins were submitted to SDS-PAGE in $7 \%$ polyacrylamide gel, except for ERK1 and ERK2 proteins which were submitted to a $10 \%$ polyacrylamide gel electrophoresis. Proteins were then electrotransferred onto a nitrocellulose membrane using a semi-dry apparatus (Multiphore II; Pharmacia LKB, Uppsala, Sweden). The membranes were incubated overnight at room temperature in blocking buffer $(10 \mathrm{mmol} / \mathrm{l}$ Tris- $\mathrm{HCl}, \mathrm{pH} 7.5$, $150 \mathrm{mmol} / \mathrm{l} \mathrm{NaCl}, 1 \mathrm{mmol} / \mathrm{l}$ EDTA, $0.2 \%$ Tween- $20,3 \%$ bovine serum albumin).

Membranes were then incubated for $3 \mathrm{~h}$ with the following antibodies: MAP2K antibody which recognized both isoforms ERK-1 and ERK-2 (MAB3054, Chemicon International, Temecula, Calif., USA), antiphosphotyrosine antibody (PY20; Chemicon) anti-PI3K antibody (PI3K; Chemicon) antiRAF-1K antibody (RAF-1K, Santa Cruz). Membranes were revealed by enhanced chemoluminescence according to the manufacturer's instructions.

In order to determine the amount of IR present in each preparation, the antiphosphotyrosine (PY-20) antibody was stripped-off by incubation of the membranes for $2 \mathrm{~min}$ in a buffer containing $0.2 \% \mathrm{SDS}, 50 \mathrm{mmol} / \mathrm{l}$ glycine and $24 \mathrm{mmol} / \mathrm{l}$ $\mathrm{HCl}$ ( $\mathrm{pH}$ 2.6). Membranes were then reprobed with a polyclonal antiinsulin receptor antibody (Ros-2, dilution 1:500), kindly provided by Prof. K. Siddle (University of Cambridge, UK) and revealed by enhanced chemoluminescence.

MAP kinase assay. Adipocytes from control and VMH rats were incubated in the absence or presence of insulin $(67 \mathrm{nmol} / \mathrm{l})$ at $37^{\circ} \mathrm{C}$ for $5 \mathrm{~min}$. Proteins were extracted as described previously. Equivalent amounts of proteins were incubated for $2 \mathrm{~h}$ at $4{ }^{\circ} \mathrm{C}$ with a mixture containing $2.5 \mu \mathrm{g}$ of antiERK1 and $2.5 \mu \mathrm{g}$ of anti-ERK2 antibodies and $10 \mathrm{mg}$ of protein-A sepharose. After immunoprecipitation, the pellets were washed four times with $1 \mathrm{ml}$ of buffer containing $50 \mathrm{mmol} / \mathrm{l} \mathrm{Tris,} 100 \mathrm{mmol} / \mathrm{l} \mathrm{NaCl}, 5 \mathrm{mmol} / \mathrm{l}$ EDTA, $1 \%$ Triton $\mathrm{X}-100,30 \mathrm{mmol} / 1 \mathrm{NaF}, 0.4 \mathrm{mmol} / 1 \mathrm{Na}_{3} \mathrm{Vo}_{4}, 1 \mathrm{mmol} / 1 \mathrm{PMSF}$ and $1 \mu \mathrm{g} / \mathrm{ml}$ each of aprotinin, pepstatin, antipain and leupeptin, then one time with $1 \mathrm{ml}$ of the kinase reaction buffer $(20 \mathrm{mmol} / \mathrm{l}$ HEPES, $1 \mathrm{mmol} / 1$ dithiothreitol, $10 \mathrm{mmol} / 1$ $\mathrm{MgCl} 2,50 \mu \mathrm{mol} / \mathrm{l} \mathrm{ATP})$. The reactions were initiated by adding the kinase reaction buffer containing $0.25 \mu \mathrm{g} / \mu \mathrm{l}$ of myelin basic protein and $0.5 \mu \mathrm{Ci}$ of $[\gamma-32 \mathrm{P}] \mathrm{ATP}$ in a final volume of
$40 \mu \mathrm{l}$. After incubation for $10 \mathrm{~min}$ at $30^{\circ} \mathrm{C}$, the reactions were arrested by the addition of $10 \mu \mathrm{l}$ of SDS/PAGE sample buffer. The mixtures were boiled for $5 \mathrm{~min}$ and subjected to SDSPAGE in $12 \%$ polyacrylamide gel.

Protein assay. The protein assay was performed as previously described [19] using bovine serum albumin as standard.

Preparation of total cellular mRNA. Total RNA was extracted from $500 \mathrm{mg}$ of WAT using the guanidine thiocyanate method [20] and the RNA solution was stored at $-80^{\circ} \mathrm{C}$. The concentration of RNA was determined by measuring the absorbance at $260 \mathrm{~nm}$. All samples had an $\mathrm{A}_{260} / \mathrm{A}_{280}$ ratio of about 1.8-2.

Northern blot analysis. Total RNA $(20 \mu \mathrm{g})$ was denatured by heating at $95^{\circ} \mathrm{C}$ for $2 \mathrm{~min}$ in $2.2 \mathrm{mmol} / \mathrm{l}$ formaldehyde and $50 \%$ (vol/vol) formamide, and size-fractionated by electrophoresis in $1 \%$ agarose gel for $16-18 \mathrm{~h}$ at $60 \mathrm{~V}$ and then transferred onto a nylon membrane (Hybond N; Amersham).

Blots were hybridized successively with several cDNA probes. A hamster ERK-1 probe was kindly provided by Dr. G.L'Allemain (Université de Nice, France), the FAS probe and the PEPCK probe were as described previously [21]. These probes were labelled with $\left[\alpha-{ }^{32} \mathrm{P}\right]$ dCTP using a rediprime labelling system kit. Hybridization conditions were performed as described previously [21-23]. The blots were exposed for 6-48 h at $-80^{\circ} \mathrm{C}$ with intensifying screens. Quantification was performed by densitometric scanning.

Statistical analysis. Results are expressed as mean \pm SEM. Statistical analysis was performed by Student's t-test for unpaired data.

\section{Results}

Characteristics of VMH-lesioned animals. One week after the lesion, body weight and periovarian adipose tissue weight were much higher in VMH compared to controls rats (Table 1). Adipocyte volume and protein content per cell were significantly higher in VMH-lesioned rats compared to controls (Table 1). This suggested that an increase in adipocyte size was involved in the enlargement of adipose tissue mass.

E ffect of insulin on the tyrosine kinase activity of the insulin receptor in intact adipocytes. After cell isolation, adipocytes were numbered with an haematocytometer under light microscopy. An equivalent number of cells from control and VMH-lesioned rats were incubated in the absence or presence of insulin for $5 \mathrm{~min}$. After cell extraction, IR were immunoprecipitated with CT1 antibody and the phosphorylation of the $\beta$-subunit on tyrosine residues was measured by immunoblotting with an antiphosphotyrosine antibody (PY-20 antibody). In the absence of insulin, the phosphotyrosine content of the $\beta$-subunit of the receptor was barely detectable in both control and VMH-lesioned rats (Fig. 1 A). Insulin strongly stimulates the autophosphorylation of the $\beta$-subunit of the receptor on tyrosine residues. Densitometric analysis of the autoradiographs (Table 2) shows that 
Table 1. Characteristics of control and VMH rats 1 week after the $\mathrm{VMH}$ lesion

\begin{tabular}{|c|c|c|c|c|}
\hline & $n$ & Control & VMH & $P$ value \\
\hline Body weight (g) & 10 & $239 \pm 5$ & $303 \pm 4$ & $<0.001$ \\
\hline $\begin{array}{l}\text { Periovarian adipose } \\
\text { tissue weight (mg) }\end{array}$ & 5 & $14 \pm 3$ & $59 \pm 3$ & $<0.001$ \\
\hline $\begin{array}{l}\text { Adipocyte volume } \\
\left(\mu \mathrm{m} 3 \times 10^{5}\right)\end{array}$ & 5 & $2.03 \pm 0.21$ & $5.03 \pm 0.68$ & $<0.01$ \\
\hline $\begin{array}{l}\text { Protein content } \\
\text { (mg/mg DNA) }\end{array}$ & 5 & $2.62 \pm 0.47$ & $6.53 \pm 0.83$ & $<0.01$ \\
\hline
\end{tabular}

Values are mean \pm SEM. $n$ represents number of experiments for each value. $P$ value indicates significance of the difference when compared to control

Table 2. Insulin receptor and intracellular protein tyrosine phosphorylation in adipocytes from control and VMH rats

\begin{tabular}{|c|c|c|c|c|}
\hline & \multicolumn{3}{|c|}{ Tyrosine phosphorylation } \\
\hline & & $\beta$-subunit & pp130-190 & pp60 \\
\hline Contr & $\begin{array}{r}1-\text { Ins } \\
+ \text { Ins }\end{array}$ & $\begin{array}{c}30 \pm 4 \\
650 \pm 85\end{array}$ & $\begin{array}{l}288 \pm 78 \\
784 \pm 74\end{array}$ & $\begin{array}{r}371 \pm 228 \\
1339 \pm 235\end{array}$ \\
\hline VMH & $\begin{array}{l}- \text { Ins } \\
+ \text { Ins }\end{array}$ & $\begin{array}{c}35 \pm 5 \mathrm{NS} \\
950 \pm 160 \mathrm{NS}\end{array}$ & $\begin{array}{l}377 \pm 72 \mathrm{NS} \\
879 \pm 207 \mathrm{NS}\end{array}$ & $\begin{array}{c}437 \pm 62 \text { NS } \\
1433 \pm 354 \text { NS }\end{array}$ \\
\hline
\end{tabular}

Results are expressed in arbitrary units as mean \pm SEM for five independent experiments. NS, Non-significantly different from control

the phosphotyrosine content of the insulin receptor $\beta$-subunit per cell was not significantly different in the two groups of adipocytes. Reprobing the membrane (Fig. 1B) with an antibody directed against the C-terminus end of the $\beta$-subunit (Ros- 2 antibody) clearly shows that the number of receptors in the VMH-lesioned rats was markedly increased compared to control rats. Densitometric analysis indicated that insulin-receptor expression was $2.2 \pm$ 0.4 times higher in VMH compared to control rats $(p<0.05, n=5)$. Such an increase of insulin receptor number in adipocytes from VMH rats has already been reported by Kasuga et al. [24]. This suggests that the autophosphorylation of the $\beta$-subunit per receptor is rather lower in VMH rats than in control rats.

In order to determine whether the activity of IR towards its physiological substrates was modified in VMH rats, we studied the effect of insulin on the tyrosine phosphorylation of cellular proteins in intact adipocytes. After immunoprecipitation of the insulin receptor, the cell extracts were incubated with hydroxyapatite [16]. After SDS-PAGE, the level of phosphorylation on tyrosine residues of proteins absorbed on hydroxyapatite was measured by immunoblotting with PY-20 antibody. As described previously [16], insulin strongly stimulates the phosphorylation of two major groups of proteins collectively named pp60 and pp130-190 respectively (Fig.1C). Pp130-190 migrated on SDS-PAGE like a
(A)

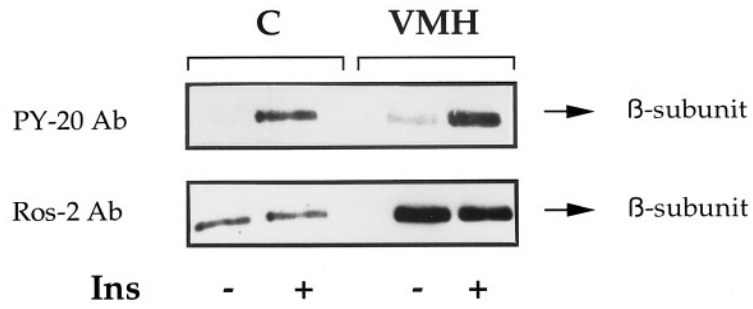

(C)

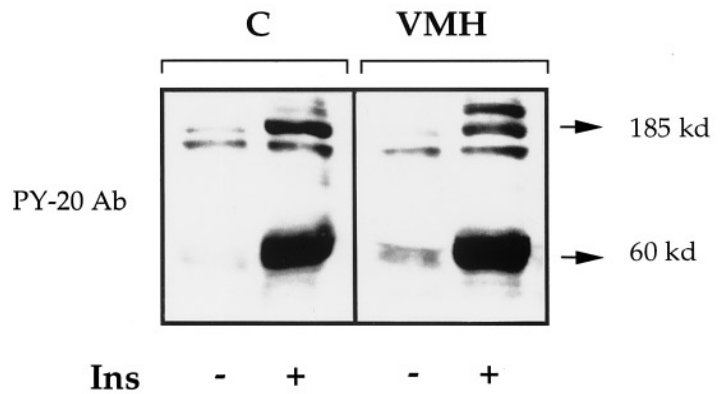

Fig. 1A - C. Equivalent number of adipocytes from control and VMH rats incubated for $5 \mathrm{~min}$ in absence or presence of insulin $(67 \mathrm{nmol} / \mathrm{l})$. Insulin receptors were immunoprecipitated with CT1 antibody and were submitted to Western blotting as described in the Experimental Procedures. Membranes were probed with either the antiphosphotyrosine antibody PY20 (A) or the anti-insulin receptor $\beta$-subunit antibody Ros2 (B). A representative experiment is shown. After immunoprecipitation with the CT1 antibody, the proteins remaining in the supernatant were absorbed onto hydroxyapatite and submitted to Western blotting. Membranes were then probed with the antiphosphotyrosine antibody PY-20 (C). A representative experiment is shown

heterogenous group of proteins with an apparent molecular weight of approximately $130-190 \mathrm{kd}$. This group of proteins is likely to include insulin receptor substrates 1 and 2 (IRS1 and IRS2) which have apparent molecular weights of 185 and $190 \mathrm{kd}$, respectively. Densitometric analysis of the autoradiographs shows that the effect of insulin on the phosphorylation of pp130-190 and pp60 is similar in the adipocytes of control and VMH rats (Table 2). Thus, the increased insulin responsiveness observed in adipocytes of VMH animals is unlikely to be due to an increased tyrosine kinase of the IR towards its intracellular substrates.

Western blotting analysis of enzymes involved in the insulin signalling pathway: PI $3 \mathrm{~K}, \mathrm{RAF}-1$ kinase and MAPK. In order to determine whether changes in the cellular content of key signal transduction proteins could be involved in the hyper-responsiveness to insulin in WAT of VMH rats, we have studied the expression of PI3K, RAF-1K and the MAPK isoform ERK-1.

Soluble extracts from an equivalent number of adipocytes of control and VMH-lesioned rats were incubated with antibodies against PI3K, RAF-1K or 
C VMH1

PI3K

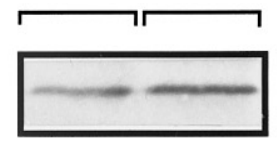

$\rightarrow 85 \mathrm{kd}$

Raf1-K

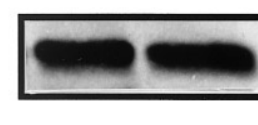

$\rightarrow 74 \mathrm{kd}$

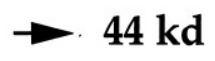

\section{ERK-1}

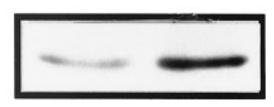

$\rightarrow 44 \mathrm{kd}$

Fig. 2. Expression of key enzymes involved in insulin signalling pathway. Equivalent numbers of adipocytes from control and $\mathrm{VMH}$ rats were incubated for $5 \mathrm{~min}$ in presence or absence of insulin. After immunoprecipitation with specific antibodies, the relative amount of PI3K, Raf-1K and ERK-1 proteins was estimated by Western blotting with specific antiPI3K, anti-Raf-1K and anti-ERK-1 antibodies. Representative experiments are shown

ERK-1. The immunoprecipitated proteins were submitted to SDS-PAGE and quantified by immunoblotting. We observed no difference in the amount of PI3K and Raf1-K (Fig.2) in the two groups of rats. In contrast, ERK-1 protein level per adipocyte was much higher in VMH compared to control rats. Densitometric analysis of five experiments indicated that the amount of ERK-1 per adipocyte was increased by $7.5 \pm 1.3$ fold in $\mathrm{VMH}$-lesioned rats compared to control rats $(p<0.001)$. Similar results were obtained when the proteins from total cell extracts were adsorbed on hydroxyapatite and submitted to Western blotting without specific immunoprecipitation, indicating that the observed differences between control and $\mathrm{VMH}$ rats could not be due to artefactual recoveries during the immunoprecipitation procedure of ERK-1 protein.

ERK-1 mRNA expression. Since ERK-1 protein is over-expressed in WAT of VMH rats, we have measured the level of ERK-1 mRNA in adipose tissue of control and VMH rats. As internal controls, we studied the mRNA expression of two important metabolic enzymes, fatty-acid synthase (FAS) and phosphoenolpyruvate carboxykinase (PEPCK) which are subjected to important hormonal and nutritional regulation in WAT [22, 25]. Representative Northern blot hybridizations with cDNA encoding for FAS, PEPCK and ERK-1 are shown in Figure 3. The densitometric analysis of seven experiments revealed that 1 week after the VMH lesion the FAS mRNA expression was markedly increased (6-fold, $p<0.01)$ in WAT of VMH rats, in agreement with previous results [3]. PEPCK mRNA expression was markedly decreased $(10$-fold, $p<0.05)$ in WAT of VMH rats,

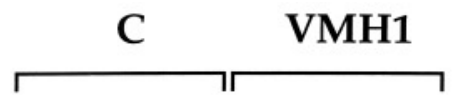

ERK-1

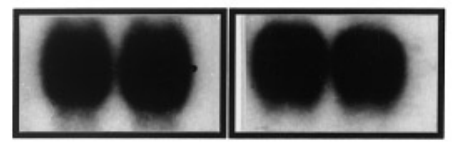

$1.8 \mathrm{~kb}$

FAS

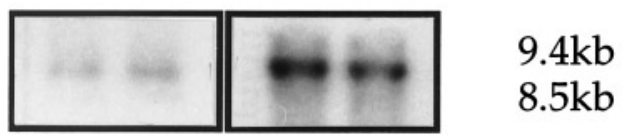

PEPCK

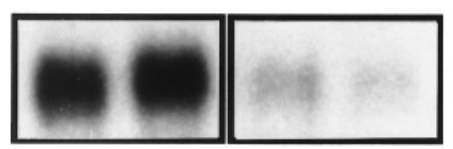

$5.5 \mathrm{~kb}$

Fig. 3. Northern blot analysis of ERK-1, FAS and PEPCK mRNA in control and VMH rats. Total RNA $(20 \mu \mathrm{g})$ from periovarian WAT of control and VMH rats was loaded in each lane. A representative Northern blot hybridized with ERK-1, FAS and PEPCK probes is shown

in agreement with the well-known opposite regulation of FAS and PEPCK in WAT by modification of the hormonal and nutritional environment $[22,26]$.

In contrast, no significant change in ERK-1 mRNA expression in the WAT of VMH animals was observed ( $n=7$, Fig. 3 ).

ERK-1 and ERK-2 specific expression and activity. Since the total protein content per cell was increased in adipocytes of $\mathrm{VMH}$ rats (Table 1), it was important to determine whether the increase in ERK-1 protein observed per adipocyte was not simply a reflection of the general increase in protein content. For this purpose, proteins were extracted from WAT of control and VMH rats. Cellular extracts were then adjusted in order to incubate equivalent amounts of total proteins from control and VMH adipocytes with a mixture containing anti-ERK1 and anti-ERK2 antibodies as described in the experimental procedures section. ERK-1 and ERK-2 expression was assessed by immunoblotting (Fig. 4 A). Densitometric analysis of four experiments indicated that, when normalized per milligram of protein, the amounts of ERK-1 and ERK-2 remained respectively, 2.2-fold $(p<0.001)$ and 3.2-fold $(p<0.05)$ higher in VMH compared to controls. This suggested that ERK-1 and ERK-2 protein expression was specifically increased in $\mathrm{VMH}$ rats.

To determine whether the higher level of MAPK protein in the WAT of VMH was associated with an increased insulin-simulated MAPK activity, we measured the activity of ERK-1 and ERK-2 immunoprecipitated from adipocytes incubated in the presence or absence of insulin for $5 \mathrm{~min}$. After insulin stimulation of adipocytes from control and VMH rats, proteins were extracted as previously described. The cell extracts were adjusted in order to incubate 
(A)

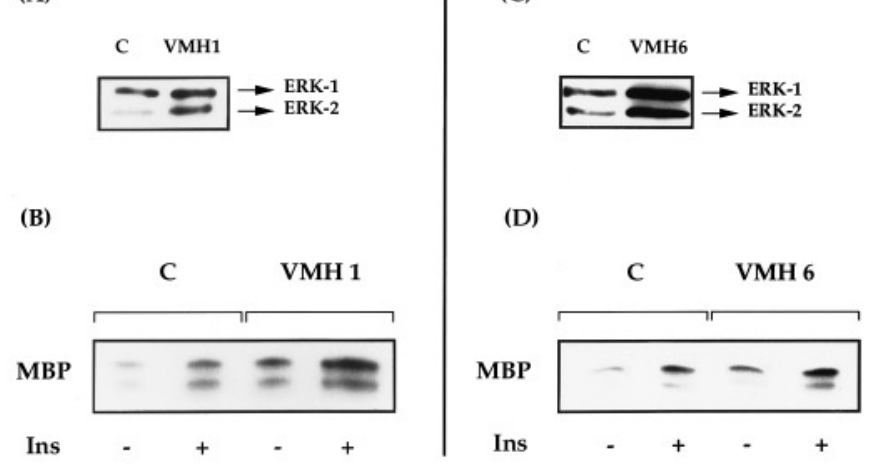

Fig. 4A-D. ERK-1 and ERK-2 expression and activity in WAT of control and VMH rats, 1 and 6 weeks after the VMH lesion. Proteins from adipose tissue of control and VMH rats were extracted as described in Experimental Procedure, 1 week after the VMH lesion (A) and 6 weeks after the VMH lesion (C). Equivalent amounts of extracted proteins were incubated with a mixture containing anti-ERK-1 and anti-ERK2 antibodies. After immunoprecipitation, the relative amount of ERK-1 and ERK-2 proteins were evaluated by Western blotting with MAP2K antibody. Representative experiments are shown. For determination of MAPK activity, adipocytes from control and $\mathrm{VMH}$ rats were incubated for $5 \mathrm{~min}$ in the absence or presence of insulin, 1 week after the VMH lesion (B) and 6 weeks after the VMH lesion (D). Proteins were extracted as described in Experimental Procedure. Equivalent amounts of extracted proteins were incubated with a mixture containing anti-ERK-1 and anti-ERK-2 antibodies. MAPK activity was assessed by studying the phosphorylation of myelin basic protein (MBP) in (ERK-1/ERK-2) immunoprecipitates from non-stimulated or insulin-stimulated adipocytes. Typical autoradiograms are presented

equivalent amounts of proteins with anti-ERK-1 and anti-ERK-2 antibodies. ERK-1 and ERK-2 activities towards MBP were measured in vitro as described in the method section (Fig. 4B). Basal and insulin-stimulated activity of MAP-kinases were higher in adipocytes from VMH than from control rats (Fig. $5 \mathrm{~A}$ ). Thus, the increase of ERK-1 and ERK-2 protein expression in WAT leads to an increase of ERK-1 and ERK-2 activity.

After VMH lesions, there is an initial period of weight gain (dynamic phase) followed by a slowing in the rate of weight gain (static phase) [1]. In order to study whether the overexpression of MAPK proteins persists during the course of obesity, we quantified MAPK 6 weeks after the VMH lesion (Fig. 4C). In the static phase of obesity, the expression of ERK-1 and ERK-2 per milligram of protein was still higher for an equivalent amount of cell protein, in WAT of obese compared to control animals. Densitometric analysis of six experiments indicated that the amount of ERK-1 and ERK-2 expression remained respectively 1.7 -fold and 1.8 -fold $(p<0.01)$ higher in VMH compared to control rats. The MAPK activity towards myelin basic protein, expressed per milligram of protein, was also higher both in the absence and presence of insulin (Fig.4D, Fig. 5B). These

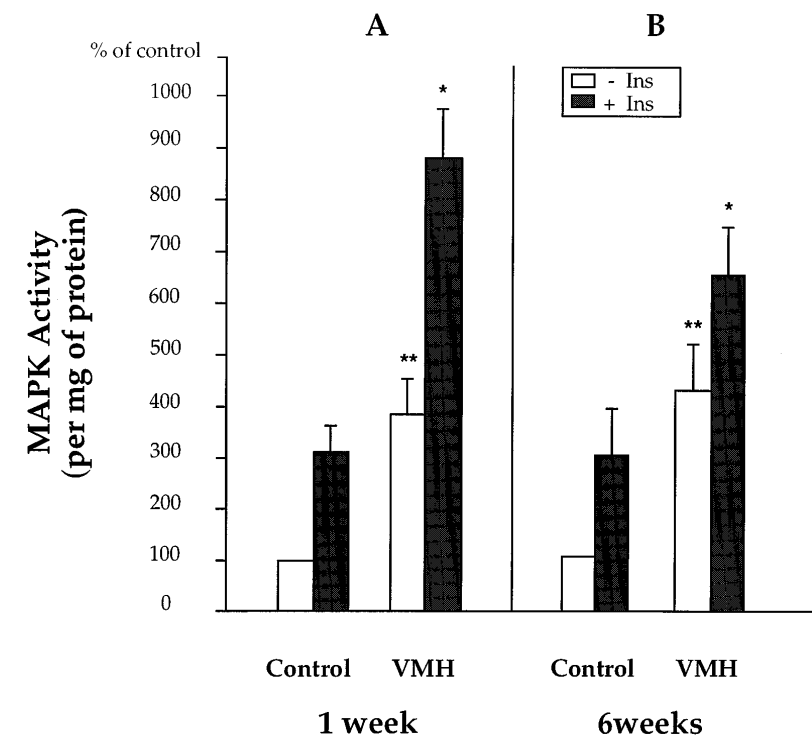

Fig. 5A , B. MAPK activity in response to insulin in adipocytes from control and $\mathrm{VMH}$ rats, 1 (A) and 6 weeks (B) after the $\mathrm{VMH}$ lesion. MAP-K activity, per milligram of protein, was measured as the phosphorylation of MBP and quantitated by densitometric analysis. Data are expressed as \% of control in absence of insulin and represent the mean \pm SEM of four independent experiments. Significantly different from control $p<0.01 ; p<0.001$

results indicate that the expression and activity of ERK1 and ERK2 proteins remain elevated in WAT of $\mathrm{VMH}$ rats well after the initial dynamic phase of obesity.

\section{Discussion}

The current model of insulin transmembrane signalling involves activation of the IR $\beta$-subunit tyrosine kinase upon insulin binding and subsequent phosphorylation of the receptor itself and of intracellular proteins on tyrosine residues. In this work we have investigated severals steps of insulin signalling pathways in order to determine whether changes in the expression or in the activity of these proteins could explain the modifications of insulin sensitivity observed in WAT of VMH rats. During the dynamic phase of obesity, the tyrosine kinase activity of the insulin receptor expressed per cell is not different in the two groups of adipocytes, and would even appear to be lower in VMH rats if corrected for the higher amount of insulin receptor per adipocyte in these animals. These results are in contrast with those obtained by Pujol et al. [27] who observed an increased tyrosine kinase activity per receptor in WAT of VMH rats. This discrepancy could be due to the different methodologies used. Pujol et al. [27] studied the autophosphorylation and the tyrosine-kinase activity of the insulin receptor in vitro using partially purified receptors and artificial peptides as substrates. It is now becoming 
apparent that results obtained in vitro may not reflect the situation in intact cells, probably because of the loss of relevant regulatory proteins during the purification procedure $[18,28]$. In contrast, in the present work, we studied in intact adipocytes the effect of insulin on the autophosphorylation of the $\beta$-subunit and on the phosphorylation on tyrosine residues of physiological substrates of the insulin receptor. Our results suggest that insulin receptor tyrosine kinase activity does not play a significant role in the variations of insulin action on WAT during the development of VMH obesity.

This study revealed that MAPK was overexpressed in adipose tissue of VMH rats at the protein level. ERK-1 protein was over-expressed in adipocyte of VMH-lesioned rats whereas the ERK-1 mRNA content was similar in the two groups of animals. This suggests that overexpression of ERK-1 was rather due to a post-transcriptional mechanism. Hyperinsulinaemia is one of the main obvious features of $\mathrm{VMH}$-induced obesity. It now appears that the regulation of the translation is an important mechanism by which insulin stimulates the expression of cellular proteins [29]. Insulin can preferentially stimulate translation of mRNA whose 5'untranslated region exhibits significant secondary structure by activating initiation factors involved in melting such secondary structures [30]. Whether such a mechanism could play a role in the increased expression of MAP-K protein in WAT of $\mathrm{VMH}$ rats remains to be demonstrated.

We observed in WAT of VMH rats an important increase in both ERK-1 and ERK-2 protein expression leading to an increased basal and insulin-induced activity. It is not clear whether MAPK plays a significant role in the transmission of the metabolic effects of insulin [31]. In contrast, MAPK are very likely to be involved in insulin stimulated cell growth. Indeed, no increase in the expression of ERK1 and ERK2 proteins was observed in the livers of obese and VMH rats (results not shown), suggesting that the overexpression of the MAPK could be a specific feature of the tissue which undergoes important growth during obesity, i.e. the WAT. One week after the lesion, VMH adipocytes are characterized by an enhanced lipid accretion resulting in an enlargement of the size of fat cells as well as an increase in protein content per cell. Similar increases in protein content have been observed previously in WAT of obese $\mathrm{VMH}[3,12,27]$ and in Zucker rats [32]. Although the potential role of MAPK in the regulation of protein synthesis is controversial [31, 33-35], it cannot be excluded that the overexpression of MAPK in WAT of VMH rats could play a role in the general increase in protein content in adipocytes of obese rats. On the other hand, it has been shown in NIH3T3 fibroblasts that ERK-2 activation in vivo correlated with enhanced activation of RNA polymerase II [36, 37]. Thus, MAPK overexpression could also contribute to the adipocyte growth by increasing the transcriptional activity of RNA polymerase II.

The increase of WAT mass in VMH rats is due to an increase of the adipocyte size but also of the adipocyte number [38]. It has been shown that MAPK induces re-entry into the cell cycle, implicating MAPK in the transmission of proliferative signals $[39,40]$. Inhibition of MAPK, by expressing p44 ${ }^{\text {Mapk }}$ antisense in fibroblasts, markedly reduces colony number and then decreases cell proliferation [39] whereas overexpression of MAPK promotes fibroblast proliferation [41]. Moreover, it has been shown that activation of MAPK increases the proliferation of white preadipocytes [42]. ERK-2 also activates c-myc [43] which is implicated in the ability of preadipocytes to respond to mitogenic signals and to undergo in vitro clonal expansion [44]. Thus, MAPK may be involved in promoting cell proliferation in adipose tissue during VMH obesity.

MAPK could also play a role in the differentiation of preadipocytes into adipocytes. Some studies have demonstrated that overexpression of $\mathrm{C} / \mathrm{EBP} \beta$ in NIH3T3 cells can induce adipogenesis in the presence of adipogenic inducers [45]. Expression of $\mathrm{C} /$ $\mathrm{EBP} \beta$ in NIH3T3 cells activates the synthesis of PPAR $\gamma$ mRNA that stimulates their conversion into adipocytes [46]. It has been shown that MAPK initiates the activation of $\mathrm{C} / \mathrm{EBP} \beta$ by phosphorylation $[47,48]$, suggesting that MAPK could be involved in adipocyte differentiation.

Thus, a sustained increase of MAPK expression and activity in WAT of VMH rats could play a significant role in the growth of adipose tissue observed during the development of VMH obesity. The mechanism by which lesion of VMH induces ERK-1 and ERK-2 overexpression remains to be elucidated.

A cknowledgements. This work was supported by a grant from the agreement ALFEDIAM-Lilly laboratories (France). M.C.-S. holds a grant from the Ministère de l'Enseignement Supérieur et de la Recherche. We are grateful to Prof. K. Siddle for providing us with anti-insulin receptor antibodies and to Dr. G.L'Allemain for providing us with the ERK-1 probe. We thank Dr. I.Lecomte for her useful technical advice for the determination of MAPK activity. We also thank Lipha laboratories (Chilly-Mazarin, France) for allowing us to use their stereotaxic equipment.

\section{References}

1. Bray GA, York DA (1979) Hypothalamic and genetic obesity in experimental animals: an autonomic and endocrine hypothesis. Physiological Reviews 59: 719-809

2. Pénicaud L, Ferré P (1988) Development of insulin resistance during the course of obesity: lessons from animal models. J Obes Weight Reg 7: 91-109

3. Cousin B, Agou K, Leturque A et al. (1992) Molecular and metabolic changes in white adipose tissue of the rat during developpement of ventromedial hypothalamic obesity. Eur J Biochem 207: 377-382

4. White MF, Kahn CR (1994) The insulin signaling system. J Biol Chem 269: 1-4 
5. Davis RJ (1993) The mitogen-activated protein kinase signal transduction pathway. J Biol Chem 268: 14553-14556

6. Carvalho CRO, Brenelli SL, Silva AC et al. (1996) Effect of aging on insulin receptor, insulin receptor substrate-1, and phosphatidylinositol-3-kinase in liver and muscle of rats. Endocrinology 137: 151-159

7. Giorgino F, Chen JH, Smith RJ (1992) Changes in tyrosine phosphorylation of insulin receptors and a 170,000 molecular weight nonreceptor protein in vivo in skeletal muscle of streptozotocin-induced diabetic rats: effects of insulin and glucose. Endocrinology 130: 1433-1444

8. Heydrick SJ, Gautier N, Olichon-Berthe C et al. (1995) Early alteration of insulin stimulation of PI3-kinase in muscle and adipocyte from gold thioglucose obese mice. Am J Physiol 268: E604-612

9. Saad MJA, Araki E, Miralpeix M et al. (1992) Regulation of insulin-receptor substrate-1 in liver and muscle of animal models of insulin resistance. J Clin Invest 90: 1839-1849

10. Heydrick SJ, Jullien D, Gautier N et al. (1993) Defect in skeletal muscle phosphatidylinositol-3-kinase in obese insulin-resistant mice. J Clin Invest 91: 1358-1366

11. Chang P-Y, Le Marchand-Brustel Y, Cheathman LA et al. (1995) Insulin stimulation of mitogen-activated protein kinase, p90rsk, and p70 S6 kinase in skeletal muscle of normal and insulin-resistant mice. J Biol Chem 270: 29 928-28935

12. Pénicaud L, Kinebanyan MF, Ferré P et al. (1989) Development of VMH obesity: in vivo insulin secretion and tissue insulin sensitivity. Am J Physiol 257: E255-E260

13. Sjöström L, Björntorp P, Vrana J (1971) Microscopic fat cell size measurements on (frozen)cut adipose tissue in comparison with automatic determinations of osmium-fixed fat cell. J Lipid Res 12 : $521-530$

14. Labarca C, Paigen K (1980) A simple rapid, and sensitive DNA assay procedure. Anal Biochem 102: 344-352

15. Rodbell M (1964) Metabolism of fat cells. Effects of hormones on glucose metabolism and lipolysis. J Biol Chem 239: 375-380

16. Issad T, Combettes M, Ferré P (1995) Isoproterenol inhibits insulinstimulated tyrosine phosphorylation of the insulin receptor without increasing its serine/threonine phosphorylation. Eur J Biochem 234: $108-115$

17. Ganderton RH, Stanley KK, Field CE et al. (1992) A monoclonal anti-peptide antibody reacting with the insulin receptor $\beta$-subunit. Characterization of the antibody and its epitope and use in immunoaffinity purification of intact receptors. Biochem J 288: 195-205

18. Issad T, Tavaré J, Denton RM (1991) Analysis of insulin receptor phosphorylation sites in intact rat liver cells by two-dimensional phosphopeptide mapping. Predominance of the trisphosphorylated form of the kinase domain after stimulation by insulin. Biochem $\mathrm{J}$ 275: 15-21

19. Bradford MM (1976) A rapid and sensitive method for the quantification of microgram quantities of protein utilizing the principle of protein-dye binding. Analyt Biochem 72: 248-254

20. Chomcznski P, Sacchi N (1987) Single-step method of RNA isolation by acid guanidinium thiocyanate-phenol-chloroform extraction. Anal Biochem 162: 156-159

21. Foufelle F, Gouhot B, Pégorier JP et al. (1992) Glucose stimulation of lipogenic enzyme gene expression in cultured white adipose tissue. J Biol Chem 267: 20543-20546

22. Coupé C, Perdereau MF, Ferré P et al. (1990) Lipogenic enzyme activities and mRNA in rat adipose tissue during weaning: role of the diet. Am J Physiol 258: E126-E133

23. Maisonpierre PC, Belluscio L, Squinto S et al. (1990) Neurotrophin-3: a neurotrophic factor related to NGF and BDNF. Science 247: 1446-1451

24. Kasuga M, Inoue S, Akanuma Y et al. (1980) Insulin receptor function and insulin effects on glucose metabolism in adipocytes from ventromedial hypothalamus-lesioned rats. Endocrinology 107: 1549-1555

25. Hopgood MF, Ballard FJ, Reshef L et al. (1973) Synthesis and degradation of phosphoenolpyruvate carboxykinase in rat liver and adipose tissue. Changes during a starvation-refeeding cycle. Biochem J 134: 445-453

26. Girard J, Perdereau D, Foufelle F et al. (1994) Regulation of lipogenic enzyme gene expression by nutrients and hormones. FASEB 8: $36-42$
27. Pujol A, Cousin B, Burnol AF et al. (1992) Insulin receptor kinase activity in muscles and white adipose tissue during course of VMH obesity. Am J Physiol 262: E161-E166

28. White MF, Takayama S, Kahn CR (1985) Differences in the sites of phosphorylation of the insulin receptor in vivo and in vitro. J Biol Chem 260: 9470-9478

29. Levenson RM, Nairn AC, Blackshear PJ (1989) Insulin rapidly induces the biosynthesis of elongation factor 2. J Biol Chem 264: 11904-11911

30. Manzella JM, Rychlik W, Rhoads RE et al. (1991) Insulin induction of ornithine decarboxylase. J Biol Chem 266: 2383-2389

31. Denton RM, Tavaré JM (1995) Does mitogen-activated-protein kinase have a role in insulin action? The cases for and against. Eur J Biochem 227: 597-611

32. Guerre-Millo M, Lavau M, Horne JS et al. (1985) Proposed mechanism for increased insulin-mediated glucose transport in adipose cells from young, obese Zucker rats. J Biol Chem 260: 2197-2201

33. Azpiazu I, Saltiel AR, DePaoli-Roach AA et al. (1996) Regulation of both glycogen synthase and PHAS-1 by insulin in rat skeletal muscle involves mitogen-activated protein kinase-independent and rapamycin-sensitive pathways. J Biol Chem 271: 5033-5039

34. Diggle TA, Moule SK, Avison MB et al. (1996) Both rapamycinsensitive and insensitive pathways are involved in the phosphorylation of the initiation factor-4E-binding protein (4E-BP1) in response to insulin in rat epididymal fat-cells. Biochem J 316: 447-453

35. Wiese RJ, Mastick CC, Lazar DF et al. (1996) Activation of mitogen-activated protein kinase and phosphatidylinositol 3' kinase is not sufficient for the hormonal stimulation of glucose uptake, lipogenesis, or glycogen synthesis in 3T3-L1 adipocytes. J Biol Chem 270: $3442-3446$

36. Dubois M-F, Nguyen VT, Dahmus ME et al. (1994) Enhanced phosphorylation of the C-terminal domain of RNA polymerase II upon serum stimulation of quiescent cells: possible involvement of MAP kinases. EMBO J 13: 4787-4797

37. Markowitz RB, Hermann AS, Taylor DF et al. (1995) Phosphorylation of the C-terminal domain of RNA polymerase II by the extracellular-signal-regulated protein kinase ERK2. Bioch Bioph Res Com 207: 1051-1057

38. Stern JS, Johnson PR (1978) Size and numbers of adipocytes and their implications. In: H.Katzer, R. J. Mahler (eds) Diabetes, obesity and vascular disease. Hemisphere Publishing Co., pp 303-308

39. Pagès G, Lenormand P, L'Allemain G et al. (1993) Mitogen-activated-protein kinases $\mathrm{p} 42 \mathrm{mapk}$ and $\mathrm{p} 44 \mathrm{mapk}$ are required for fibroblast proliferation. Proc Natl Acad Sci USA 90: 8319-8323

40. Brunet A, Pagès G, Pouysségur J (1994) Constitutively active mutants of MAP kinase kinase (MEK1) induce growth factor-relaxation and oncogenicity when expressed in fibroblast. Oncogene 9: 3379-3387

41. Albanese C, Johnson J, Watanabe G et al. (1995) Transforming p21ras mutants c-Ets-2 activate the cyclin D1 promotor through distinguishable regions. J Biol Chem 270: 23589-23597

42. Bouloumié A, Planat V, Devedjian JC et al. (1994) $\alpha 2$ - adrenergic stimulation promotes preadipocyte proliferation. Involvement of mitogen-activated-protein kinases. J Biol Chem 269: 30254-30259

43. Seth A, Gonzales FA, Gupta S et al. (1992) Signal transduction within the nucleus by mitogen-activated protein kinase. J Biol Chem 234: 24796-24804

44. Freytag SO (1988) Enforced expression of the c-myc oncogene inhibits cell differentiation by precluding entry into a distinct predifferentiation state in G0/G1 Mol. Cell Biol 8: 1614-1624

45. Yeh WC, Cao Z, Classon M et al. (1995) Cascade regulation of terminal adipocyte differentiation by three members of the C/EBP family of leucine zipper proteins. Genes Dev 9: 168-181

46. Wu Z, Xue Y, Bucher NLR et al. (1995) Conditional ectopic expression of $\mathrm{C} / \mathrm{EBP} \beta$ in NIH-3T3 cells induces PPARg $\gamma$ and stimulates adipogenesis. Genes Dev 9: 2350-2363

47. Nakajima T, Kinoshita S, Sasagawa Tet al. (1993) Phosphorylation at threonine-235 by a ras-dependent mitogen-activated protein kinase cascade is essential for transcription factor NF-IL6. Proc Natl Acad Sci USA 90: 2207-2211

48. Kowenz-Leutz E, Twamley G, Ansieau S et al. (1994) Novel mechanism of $\mathrm{C} / \mathrm{EBP} \beta$ (NF-M) transcriptional control: activation through derepression. Genes Dev 8: 2781-2791 